\title{
THE INJUSTICE OF POVERTY AND INEQUALITY AND ITS' LINKS TO REGIONAL SECURITY OF THE BALKANS
}

\author{
Ph.D. Astrid Orovcanec \\ E-mail: astridsky@yahoo.com
}

\begin{abstract}
Balkan region which due to its history is significantly multiethnic, multicultural and multireligious is consisted of post-conflict and post-transitional countries that are on a varying degree of socioeconomic and democratic development and accordingly at different stages of European and Euro-Atlantic integration. The region, mainly the West Balkan, is also characterized with wide spread poverty and inequality within the countries as well as between the countries, which makes it the least developed region in Europe. Therefore, this paper attempts to assess the influence of poverty and inequality (economic, social, political and cultural) on national and consequently on regional security. For that reason, on one hand are identified the horizontal inequalities between the Balkan countries, and on the other is analyzed their impact upon security.

The fundamental question this paper seeks to address is how poverty and inequality are affecting the peace and security specifically in the Balkan region? It is argued that the very high poverty and inequality have serious security implications i.e. they may lead to tensions (ethnical, social, political, etc.) due to the perception of injustice, undermining the trust into democracy and eventually destabilizing already fragile region.

The research results are based on the application of content analysis of numerus sources, secondary analysis of statistical data and comparative analysis. The results will show that the region is characterized with very high human insecurity due to very high poverty and inequality both on national and regional level. Since both poverty and inequality are structural challenges to security, the regional stability depends from countries' capabilities to eradicate poverty and reduce inequalities through completion of necessary structural adjustments, regional cooperation and European integration.
\end{abstract}

Keywords: Poverty, horizontal inequalities, injustice, security, democracy 


\section{Seccurity}

\section{INTRODUCTION}

Once again the situation in the Balkans is in the focus of academic and European Union (EU) debates as well as of local and international media. There are numerus articles and analysis referring to increased tensions in the region, calling Europe to pay more attention for its stabilization since it is crucial for European stability and security as well. The region today, as it was during the 1990s, is exposed to serious old and new threats and challenges to its stability and security, primarily deriving from underdevelopment and poor socioeconomic performances; the undermined democratic system; and enlargement fatigue both in the EU and the Western Balkans' (WB) countries. Traditional geopolitical issues concerning territory, borders, arms race, resources and ethnical and cultural differences are still major threats to security in the region, but they are additionally strengthened by the negative effects of global economic and social processes that are having serious security implications. In this regard, poverty and inequality in the region, particularly the WB are chronic challenges that combined with the acute threats such as the refugee crisis (2015) and other national (Bosnia and Herzegovina, Macedonia) and bilateral disputes (Croatia-Serbia; Serbia-Kosovo; Macedonia-Greece) can lead to new tensions, fragmentation and eventually to regional destabilization. At the same time the democratization of the WB countries is brought into question due to ever increasing problems with authoritarian regimes, widespread populism, poor neighborly relations, democratic deficits, absence of the rule of law, weak institutions, incomplete reforms, corruption, organized crime and etc.

Having in mind that the region is quite heterogeneous as per territorial distribution of population, characterized with extremely high unemployment, contributing to already enormous poverty and inequality it is necessary to investigate whether poverty and inequality can influence democratic development and security of the region. After the global economic crisis that was felt in 2009 and which was followed by social and political tensions, many researchers attempted to answer whether the socioeconomic and political consequences of the crisis will influence regional peace and stability. Their conclusion is that development inequalities and imbalances between the countries or ethnic communities will bring permanent instability in the future (Jeleva, 2012) and that any further delay in Euro and Euro-Atlantic integration of the region may disrupt its fragile peace and undermine its security (Bartlet, 2010). Despite the fact that Balkan region today is stabilized and quite consolidated it is still characterized with high degree of human insecurity, which varies from one to another country depending on their economic and democratic development and which may create grievances leading to tensions that may become violent and seriously undermine regional peace, stability and security. Overcoming the economic crisis and balancing the socioeconomic development of the Balkans' countries will facilitate the integration of the entire region into the $\mathrm{EU}$, regardless of the regional context and accordingly will contribute to regional peace and stability (Orovcanec, 2016).

This research that builds on previous one investigates the link between development, democracy and security in order is to explain how poverty and inequality affect human security in its three main dimensions: freedom from want, freedom from fear and freedom to live in dignity as well as their inter-relationships from theoretical and practical perspective. The results will con- 


\section{Security}

firm that very high poverty and inequality in the Balkans have serious security implications such as tensions due to injustice and violation of human rights; reduced trust in democracy; and regional destabilization. In continuation it will be necessary first to identify poverty and horizontal inequalities in the region, and then within the theoretical framework consisted of human security concept and the grievance based theories of conflict i.e. relative deprivation ${ }^{64}$ and horizontal inequality ${ }^{65}$ to assess their influence upon human and consequently upon national and regional security.

The concept of human security acknowledges the interlinkages between security, development and human rights and considers these to be the building blocks of human and, therefore, national security (Committee on Economic, Social and Cultural Rights, 2001). The term implies protection of basic human rights and freedoms and protection from various security threats. Paragraph 143 of the 2005 World Summit Outcome (A/RES/60/1) underlines "the right of all people to live in freedom and dignity, free from poverty and despair" and recognizes that "all individuals, in particular vulnerable people, are entitled to freedom from fear and freedom from want, with an equal opportunity to enjoy all their rights and fully develop their human potential". The causal mechanism through which poverty and inequality might trigger socioeconomic grievances that may initiate collective violence will be explained through the prism of Grievance theories of conflict. Central idea of these theories is that relative and not absolute position of the people is the most common cause of conflict.

\section{POVERTY AND INEQUALITY AS SOURCE OF VULNERABILITY}

After the end of the Cold war, Balkans' countries joined the implementation of structural adjustments on the basis of neoliberal doctrine in order to integrate into the global economy thus reducing its harmful effects. These structural reforms understood as comprehensive transformation of the overall society i.e. economic transition from regulated and centrally planned economy to free market economy and political transition from one party political system to multilateral liberal democracy, didn't bring the expected living standard and democratic progress particularly in the WB countries, thus causing grievances and tensions, while at the same time deepening the already deep structural problems. Increased inequality, poverty and conflict have been inter-linked phenomena during the transition processes (Spoor, 2005). Moreover, the global financial and economic crisis set back the achievements and brought in question foundations of the neoliberal capitalism and the trust into democracy. Notwithstanding the socioeconomic and democratic progress during the transition, poverty remains widespread across the region and horizontal inequalities within and between Balkan countries are continuous and serious. The slow economic growth compared

\footnotetext{
${ }^{64}$ Gurr (1970) defines relative deprivation as actors' perception of the discrepancy between their expected values and their possible values. Reference point for peoples' expectations may be some referent group, standards articulated by the leaders, abstract model, past situation etc.

65 Unlike vertical inequalities defined as income inequalities between individuals, Stewart (2002) defines horizontal inequalities as "serious inequalities between culturally defined or identity groups" usually defined according to characteristics such as class, ethnicity, geographic origin or religion and which are result of an unequal allocation of resources among them. Most obvious and formally organized identity groups are the national states.
} 


\section{Seccurity}

with increasing inequality affects the political developments by rise of populism that is not only regional, but global phenomena as well.

Economic horizontal inequalities that refer to unequal access, utilization and ownership of resources, uneven income level and employment opportunities will be identified through regional comparison of countries' economic capacity (annual GDP), performance (annual GDP growth rate), well-being (GDP per capita) and unemployment rate.

Table 1: Economic horizontal inequalities in the Balkans'

\begin{tabular}{|l|r|r|r|r|}
\hline \multicolumn{1}{|c|}{ Country } & $\begin{array}{c}\text { GDP(current us\$) } \\
\text { (million) }\end{array}$ & \multicolumn{1}{|c|}{$\begin{array}{c}\text { GDP growth } \\
\text { rate } \\
\text { (\% annual) }\end{array}$} & $\begin{array}{c}\text { GDP per capita } \\
\text { (current us\$) }\end{array}$ & $\begin{array}{c}\text { Unemployment } \\
\text { (\%) }\end{array}$ \\
\hline ALB & $11.398,39$ & 2.8 & $3.945,2$ & 16.1 \\
\hline BIH & $16.191,72$ & 3.0 & $4.249,3$ & 27.9 \\
\hline BGR & $50.199,12$ & 3.6 & $6.993,5$ & 11.6 \\
\hline HRV & $48.732,00$ & 1.6 & $11.535,8$ & 16.7 \\
\hline GRC & $194.851,32$ & -0.2 & $18.002,2$ & 26.3 \\
\hline KSV & $6.400,69$ & 3.9 & $3.561,6$ & 30.9 \\
\hline MKD & 10.086 .02 & 3.7 & $4.852,7$ & 27.9 \\
\hline MNE & $3.987,06$ & 3.2 & $6.406,1$ & 19.1 \\
\hline ROU & $177.954,49$ & 3.7 & $8.972,9$ & 7.0 \\
\hline SRB & $37.160,33$ & 0.8 & $5.235,1$ & 22.2 \\
\hline SVN & $42.774,77$ & 2.3 & $20.762,5$ & 9.5 \\
\hline
\end{tabular}

Source: The World Bank National Accounts Data and OECD National Accounts Files (2016)

Presented data show that Balkans' countries differ a lot regarding their economic capacity expressed by the annual GDP. Greece as region's oldest EU member country has the biggest economic capacity despite the current economic crisis, followed by Romania and Bulgaria. The average growth rate in the region for 2016 amounts to 2,5\% which is not enough to solve the most serious economic and social problems. Highest economic growth is registered in the poorest Balkans' countries i.e. Kosovo, Macedonia and Bulgaria, while at the same time the lowest growth is noted in Greece, Serbia and Croatia. There are significant differences regarding the GDP per capita among the Balkan countries. Highest GDP per capita is in Slovenia and it is almost six times higher than the lowest in Kosovo or five times than the one in Albania. Still, biggest problem of the regional economic model is extremely high unemployment throughout the whole transition period which indicates insufficient utilization of human resources. The average unemployment in the region is about $20 \%$. Highest unemployment, higher than $20 \%$ is registered in Kosovo, Macedonia, Greece, Bosnia and Herzegovina and Serbia, whereas the lowest unemployment is in Romania and Slovenia. 
Social horizontal inequalities imply unequal access to wide range of public services such as education, health protection and housing as well as different results from education and health services for different groups. They will be determined through regional comparison of human development indicator's (HDI) components and poverty rates.

Table 2: Social horizontal inequalities in the Balkans'

\begin{tabular}{|l|c|r|r|r|r|r|r|}
\hline Country & $\begin{array}{c}\text { Rang } \\
\text { (of 188) }\end{array}$ & \multicolumn{1}{c|}{ HDI } & \multicolumn{1}{c|}{ LEB } & \multicolumn{1}{c|}{ MYS } & \multicolumn{1}{c|}{ EYS } & \multicolumn{1}{l|}{ GNI p.c. } & \multicolumn{1}{c|}{ Gini } \\
\hline SVN & 25 & 0.880 & 80.4 & 11.9 & 16.8 & 27.852 & 24.9 \\
\hline GRC & 29 & 0.865 & 80.9 & 10.3 & 17.6 & 24.524 & 34.7 \\
\hline HRV & 47 & 0.818 & 77.3 & 11.0 & 14.8 & 19.409 & 33.6 \\
\hline MNE & 49 & 0.802 & 76.2 & 11.2 & 15.2 & 14.558 & 30.6 \\
\hline ROU & 52 & 0.793 & 74.7 & 10.8 & 14.2 & 18.108 & 27.3 \\
\hline BCR & 59 & 0.782 & 74.2 & 10.6 & 14.4 & 15.596 & 34.3 \\
\hline SRB & 66 & 0.771 & 74.9 & 10.5 & 14.4 & 12.190 & 29.7 \\
\hline MKD & 81 & 0.747 & 75.4 & 9.3 & 13.4 & 11.780 & 44.2 \\
\hline ALB & 85 & 0.733 & 77.8 & 9.3 & 11.8 & 9.943 & 29.0 \\
\hline BIH & 85 & 0.733 & 7605 & 8.3 & 13.6 & 9.638 & 33.0 \\
\hline KSV & - & 0.714 & 71.0 & - & - & 3.344 & - \\
\hline
\end{tabular}

Source: Human Development Report, 2016

According to HDI value, most of the countries in the region are with high human development, except Slovenia, Greece, Croatia and Montenegro that are with very high human development. It is evident that the countries with higher HDI value also have greater life expectancy at birth (LEB), greater mean years of schooling (MES) and higher living standard i.e. gross national income (GNI) per capita. This shows that higher human development implies better access to health protection and education as well as better living standard. Therefore, "human development contributes to human security by tackling the long term structural causes of conflict and by strengthening the capability of societies to deal with conflict in a peaceful manner" (Cilliers, cited in Hong Hai 2007: 9-10). According to Gini coefficient that measures the income inequality among individuals, greatest inequality exists in Macedonian society which is almost broken in half, then follow Bulgaria, Bosnia and Herzegovina, Croatia and Montenegro. Cini coefficient can be understood as index of relative deprivation, because very high inequality within a society may indicate hidden relative poverty ${ }^{66}$. Cenerally countries with high levels of inequality are also likely to have high levels of poverty.

${ }^{66}$ Relative poverty is when some people's way of life and income is much worse than the general standard of living in the country or region in which they live. 
Table 3: Population living below international and national poverty lines

\begin{tabular}{|c|c|c|c|c|c|c|c|c|}
\hline \multirow[b]{2}{*}{ Country } & \multirow[b]{2}{*}{ Population } & \multirow{2}{*}{$\begin{array}{c}\text { MPI } \\
(\%)\end{array}$} & \multicolumn{2}{|c|}{$1,9 \$ /$ day (\%) } & \multicolumn{2}{|c|}{$3,10 \$ /$ day $(\%)$} & \multicolumn{2}{|c|}{ Nat. poverty line } \\
\hline & & & 2002 & 2013 & 2002 & 2013 & $\%$ & $\begin{array}{l}\text { Survey } \\
\text { (year) }\end{array}$ \\
\hline ALB & 3.029 .278 & 1.2 & 2.22 & 1.02 & 15.85 & 6.37 & 14.3 & 2011 \\
\hline $\mathrm{BIH}$ & 3.867 .055 & 1.7 & 0.25 & 0.07 & 0.76 & 0.40 & 17.2 & 2011 \\
\hline BGR & 7.186 .893 & - & 1.30 & 2.03 & 5.42 & 4.78 & 21.8 & 2014 \\
\hline HRV & 4.464 .844 & - & 0.07 & 0.92 & 0.15 & 2.37 & 19.5 & 2014 \\
\hline GRC & 10.775 .643 & - & - & - & 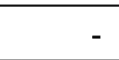 & - & 36.0 & 2014 \\
\hline KSV & 1.870 .981 & - & 1.28 & - & 12.66 & - & 30.0 & 2013 \\
\hline MKD & 2.096 .015 & 1.7 & 1.31 & 2.19 & 6.21 & 9.27 & 30.4 & 2011 \\
\hline MNE & 647.073 & 0.5 & 0.25 & 1.04 & 0.78 & 2.53 & 8.6 & 2013 \\
\hline ROU & 21.666 .350 & - & 5.40 & 0 & 22.24 & 4.05 & 22.4 & 2012 \\
\hline SRB & 7.176 .794 & 0.4 & 0.34 & 0.19 & 1.10 & 1.33 & 9.2 & 2013 \\
\hline SVN & 1.983 .412 & - & 0 & 0.03 & 0.05 & 0.05 & 13.5 & 2012 \\
\hline
\end{tabular}

Source: World Bank's PovcalNet, UNDP and the World Factbook, CIA

In table 3 poverty is presented as absolute poverty ${ }^{67}$ or a percentage of population living below international poverty lines of 1,9\$ and 3,10\$ per day and national poverty lines set by each country separately. Extreme poverty exists in the whole region with exception of Romania. Highest extreme poverty is registered in Macedonia, Bulgaria and Montenegro; while lowest is in Slovenia. Analysis of poverty below national poverty line shows that around one third of population in Greece, Kosovo and Macedonia lives in poverty. National poverty line vary from country to country, depending on the standard of living enjoyed by the majority. Multidimensional poverty index identifies the multiple deprivations at individual level in regard to health, education and living standard i.e. in the three basic dimensions of human development, thus reflecting the intensity of deprivation. Population that lives in multidimensional poverty is registered only in the WB countries, where it is highest in Macedonia and Bosnia and Herzegovina.

Political horizontal inequalities consider unequal political power distribution and peoples' ability to participate in the politics, so in that way to express their needs. Since in the focus of this research is the regional dimension of horizontal inequalities, the political ones will be recognized by comparing the level of European and Euro-Atlantic integration, which are national strategic goals of Balkans' countries establishing their international position.

\footnotetext{
${ }^{67}$ Absolute or extreme poverty is when people lack one or more basic necessities for survival (for instance food, clean water, clothing and housing) during a longer period of time.
} 
Table 4: Political horizontal inequalities in the Balkans'

\begin{tabular}{|c|c|c|}
\hline Country & NATO status & EU status \\
\hline ALB & Member country & \multirow{2}{*}{ Candidate country } \\
\hline MKD & Aspirant country & \\
\hline MNE & Aspirant country & \multirow{2}{*}{ Negotiating status } \\
\hline SRB & Individual Partnership Action Plan & \\
\hline $\mathrm{BlH}$ & Aspirant country & \multirow{2}{*}{ Potential candidate } \\
\hline KSV & Aspiring partnership for peace members & \\
\hline HRV & Member country & \multirow{5}{*}{ Member country } \\
\hline BUG & Member country & \\
\hline ROU & Member country & \\
\hline SVN & Member country & \\
\hline GRC & Member country & \\
\hline
\end{tabular}

Source: European Commission, 2017

It is clear that WB countries are marginalized concerning the wider enlargement and development process, which is contributing to the overall grievance and disappointment in the specific region. Cultural horizontal inequalities, which indicate inequalities in cultural recognition and unequal cultural status of different cultural groups are also present in the region, preventing its' further development, cooperation and integration. The case of Macedonia, where different elements of Macedonian identity are denied by some of its neighbors, is the most revealing example. Growing gap between WB and EU, as well as the rest of the Balkans may lead to continued human suffering, social unrest and resumption of conflicts.

The results indicate that there are significant socioeconomic, political and cultural horizontal inequalities in the region. Their simultaneous and enduring existence is increasing the group grievance and facilitating the political mobilization, thus increasing the risk of collective violence and violent conflicts. Even so, inequality by itself and even the relative poverty don't automatically lead to conflict, unless there are other intermediary factors deriving from political and economic processes and social and inter-ethnical relations. The multicultural character of the region by itself may be source of instability due to the perception of injustice of various ethnicities that the others are wealthier, more privileged and alike. In the case of Balkans, ethnic communities that are exceeding the national borders may stimulate regional grievances and even violence, thus leading to regional support or resistance to such extended groups through financing, arming, propaganda, political maneuvering etc. At the same time the region is exposed to continuous internal as well as external influences that are additionally stressing internal security dynamic.

Poverty and inequality as source of vulnerability violate people's fundamental "freedom from want" by directly affecting their survival, well-being and quality of life. Eradication of poverty 
in order to achieve "freedom from want" has been emphasized by the UN in the Preamble to the Universal Declaration of Human Rights and the common Preamble to the International Covenant on Civil and Political Rights and the International Covenant on Economic, Social and Cultural Rights (International Federation of Social Workers, 2017). In order to achieve and protect this freedom it is necessary to eradicate poverty and provide equality through sustainable economic and human development and inclusive and equitable growth.

\section{POVERTY AND INEQUALITY AS SOURCE OF INJUSTICE}

All human rights provided by the UN Treaties such as the right to work, fair and just working conditions, social security, adequate food, housing and clothing, health and education are crucial to enable people to live in dignity, thus eradicating poverty is also significant in achieving the "freedom to live in dignity". "In the light of the International Bill of Rights, poverty may be defined as a human condition characterized by sustained or chronic deprivation of the resources, capabilities, choices, security and power necessary for the enjoyment of an adequate standard of living and other civil, cultural, economic, political and social rights" (Committee on Economic, Social and Cultural Rights, 2001).

Issues of poverty and inequality are human rights issues and they represent injustice which appears to be a source of insecurity. In many developing countries that underwent the process of neoliberal structural adjustments, such as the Balkans' countries, the poor are victims of structural injustice, with unequal access to assets and marginalized opportunities for human development (Crockett, 2011). Violations of human rights, particularly the rights of subordinate groups may cause serious injustice and for that reason group or collective rights are as important for democratic development as they ensure an equitable distribution, equality and equity. Violations of human rights drive and deepen poverty and social exclusion because people that live in poverty have difficulties accessing power, court system and legal services, food, clean water, education, health care etc. Unlike human rights human security is not state's obligation, but it is ensured when human rights are protected consistently with the international human rights law (Hong Hai, 2007: 7-8).

Democracies should be able to go beyond the electoral politics and process to enabling human rights, physical well-being and human development, which are the building blocks of human security. In the regions, like the Balkans, characterized by inequality and poverty where important sectors of the population live in poverty, there is a demand that democracy should deliver and be effective in social and economic terms. "Only when the poor see that democracy translates into actual benefits in terms of better economic and social conditions will they value democracy over charismatic leadership and revolutionary promises". The reasons for declined trust in democracy are due to the way of implementation of democratic governance, the design of post-conflict and post-socialistic transition and liberalization reforms which caused inequalities and suppressed the welfare state. Frustration with democratic governments that are not capable of solving these most severe and pressing problems in the region may extend to democracy itself, which is evident from increasing population support of authoritarian regimes in the region. Hence, the importance 
of the improvement of democratic delivery in poverty and inequality reduction. (Large \& Sisk, 2006: 120)

"One of the most serious threats to our common security emerges from human desperation in societies which lack in respect for human rights and democracy" because democracy is driving force for a development and security. Democracy should be recognized as a political power able to transform the unjust socioeconomic structures (Large \& Sisk, 2006, p. 119). $70 \%$ of the countries which experienced democratic backtracking over the past 20 years faced periods of economic stagnancy before backsliding (Halperin, et al., 2005). In that regard the lack of progress in socioeconomic development has also contributed to a backlash against democracy due to poor economic performance; high levels of socioeconomic inequality; large gap between rich and poor; and disappointment, social frustration and at time rebellion and violence.

Bertelsmann Stiftung's transformation index (BTI) which is assessing the overall economic and political transformation was used in order to evaluate the democratic progress and the overall state of development of the Balkans' countries. The results presented in table 5 show that Slovenia is the only highly advanced country in the region with consolidated democracy and developed market economy. Romania, Croatia and Bulgaria are advanced countries with democracy in consolidation and functioning market economy. Montenegro and Serbia are also advanced countries regarding their transformation status, with functioning market economy, but defective democracy. Macedonia, Albania, Bosnia and Herzegovina and Kosovo are with limited transformation, defective democracy and market economy with functional flows, except Macedonia that is with functioning market economy.

Table 5: Transformation index of Balkans' Countries

\begin{tabular}{|l|c|c|c|c|c|c|c|}
\hline Country & \multicolumn{2}{|c|}{ BTI } & \multicolumn{2}{c|}{$\begin{array}{c}\text { Political } \\
\text { Transformation }\end{array}$} & \multicolumn{4}{c|}{$\begin{array}{c}\text { Economic } \\
\text { Transformation }\end{array}$} \\
\hline & rank & score $^{1}$ & rank & value & rank & value & $\begin{array}{c}\text { Level of socioeconomic } \\
\text { development }\end{array}$ \\
\hline Slovenia & 7 & 9,01 & 7 & 9,20 & 7 & 8,82 & 10 \\
\hline Romania & 14 & 8,06 & 17 & 8,15 & 15 & 7,96 & 7 \\
\hline Croatia & 15 & 7,93 & 14 & 8,40 & 20 & 7,46 & 8 \\
\hline Bulgaria & 16 & 7,91 & 17 & 8,15 & 18 & 7,68 & 7 \\
\hline Montenegro & 20 & 7,48 & 21 & 7,85 & 27 & 7,11 & 7 \\
\hline Serbia & 21 & 7,43 & 21 & 7,85 & 30 & 7,00 & 6 \\
\hline Macedonia & 31 & 6,86 & 44 & 6,65 & 28 & 7,07 & 6 \\
\hline Albania & 33 & 6,71 & 36 & 6,95 & 37 & 6,46 & 5 \\
\hline Bosnia & 42 & 6,38 & 54 & 6,30 & 37 & 6,46 & 6 \\
\hline Kosovo & 44 & 6,33 & 44 & 6,65 & 49 & 6,00 & 5 \\
\hline
\end{tabular}

Source: Bertelsmann Stiftung, 2016 
In accordance with the Freedom House's Nations in transition Report of 2016, there is a decline of average democratic score in the Balkans 6 years in a raw, after substantial progress from 2004 to 2010. Today region's average democratic score is the same as it was in 2004. All the regions' EU candidate and potential candidate countries are declining with exception of Albania, while the largest score decline was registered in Macedonia. From EU member countries Slovenia is the only consolidated democracy in the region, while Bulgaria, Romania and Croatia together with Serbia and Montenegro are semi consolidated democracies. Albania, Bosnia and Herzegovina and Macedonia are transitional governments or hybrid regimes, while Kosovo is semi consolidated authoritarian regime.

It is evident that despite the democratic continuity during the last 25 years and a certain economic growth and trade liberalization, the model of structural reforms did not respond to specific regions' social deficits perceived as deficits of democracy (Large $\&$ Sisk, 2006: 118). Therefore the process of euro-integration and achieving EU basic values of good governance, democracy, rule of law and human rights is contributing to reduction of human injustice by enabling people to live life in dignity. Strengthening democracy by ensuring the rule of law and independent and effective justice system is and will stay priority for the Balkans' countries, because they are crucial to economic and social stability.

\section{POVERTY AND INEQUALITY AS SOURCE OF INSECURITY}

Poverty, inequality and perceived sense of injustice they create may lead to increasing vulnerability, instability and radicalization. Sources to insecurity lie in exclusion and lack of access to power and resources of subordinate groups and people living in poverty (Large \& Sisk, 2006). With the purpose of investigating their influence upon the regional peace, stability and security, in this chapter will be analyzed some of the most relevant structural indexes for Balkans' countries.

Fragile State Index (FSI) of the Fund for Peace measures the risk of destabilization of the states and the pressure that might push them into failure. The FSI is very important in identifying the excessive pressure to which the states are exposed to and which may be crucial for their success or failure. The index is consisted of 12 indicators divided into three groups i.e. social, economic and political-military. According to the index value ${ }^{69}, 178$ countries are ranked as per their stability level in a way that enables country comparison.

Table 7: Fragile State Index for the Balkans' countries

\begin{tabular}{|c|c|c|c|}
\hline Country & Rank & Value & \multirow{2}{*}{ Stability level } \\
\hline BIH & 88 & 74.2 & \multirow{2}{*}{ Elevated warning } \\
\hline SRB & 98 & 72.0 & \multirow{2}{*}{ Warning } \\
\hline MKD & 111 & 67.0 & \\
\hline ALB & 124 & 61.2 & \multicolumn{1}{|c}{} \\
\hline GRC & 130 & 55.9 & \\
\hline
\end{tabular}

${ }^{69} \mathrm{FSI}$ 's value varies from 0 (very stable) to 115 (very unstable).

Стајић Љ. Гилановић Ч. (1994) “Основи безбедности”, Полициска академија у Београду, Београд 


\begin{tabular}{|c|c|c|c|}
\hline MNE & 131 & 55.2 & \multirow{2}{*}{ Stable } \\
\hline BUC & 132 & 53.7 & \\
\hline ROU & 134 & 52.9 & \\
\hline HRV & 136 & 52.4 & Very Stable \\
\hline SVN & 160 & 33.9 & \\
\hline
\end{tabular}

Source: Fund for Peace, 2016

According to the data presented in the table, all stable countries in the region lout of which Slovenia is very stable) are EU members' states, with exception of Montenegro which is in most progressed stage of EU integration. The WB countries are in warned category i.e. Bosnia and Herzegovina and Serbia have elevated warning, while Albania and Macedonia are warned countries. Thorough indicators' analysis shows that biggest pressure in the region is coming from poverty, group grievances, factionalized elites and refugees.

"Negative peace" means absence of hostilities usually by confrontational means such as the threat or actual use of force by police and military forces (Sandole, 2007). Therefore, negative peace may be defined as absence of violence or fear from violence which corresponds to human security's "freedom from fear". Negative peace is being measured by the Clobal Peace Index of the Institute for Economics and Peace and it is composed of 23 indicators divided into two main domains, internal and external peace.

Table 8: Global Peace Index (GPI) for the Balkans' countries

\begin{tabular}{|l|c|c|c|c|c|c|}
\hline Country & $\begin{array}{c}\text { Global } \\
\text { rank } \\
\text { (out of } \\
162 \text { ) }\end{array}$ & $\begin{array}{c}\text { Regional } \\
\text { rank } \\
\text { (out of 36) }\end{array}$ & Value $^{2}$ & Militarization & $\begin{array}{c}\text { Society } \\
\text { and } \\
\text { Security }\end{array}$ & $\begin{array}{c}\text { Ongoing } \\
\text { domestic and } \\
\text { international } \\
\text { conflict }\end{array}$ \\
\hline SVN & 10 & 7 & 1.408 & 1.3 & 1.4 & 1.5 \\
\hline HRV & 26 & 19 & 1.633 & 1.7 & 1.9 & 1.3 \\
\hline BUG & 29 & 20 & 1.646 & 1.6 & 2.1 & 1.1 \\
\hline ROU & 31 & 21 & 1.649 & 1.9 & 1.9 & 1.1 \\
\hline SRB & 48 & 28 & 1.834 & 1.7 & 2.1 & 1.6 \\
\hline ALB & 54 & 29 & 1.867 & 1.8 & 2.4 & 1.3 \\
\hline MNE & 57 & 30 & 1.884 & 1.6 & 2.3 & 1.5 \\
\hline BIH & 60 & 31 & 1.915 & 1.6 & 2.1 & 1.1 \\
\hline KSV & 77 & 33 & 2.022 & 1.5 & 2.5 & 0.8 \\
\hline GRC & 82 & 34 & 2.044 & 2.1 & 2.3 & 1.7 \\
\hline MKD & 94 & 35 & 2.092 & 1.9 & 2.4 & 1.9 \\
\hline
\end{tabular}

Source: Institute for Economics and Peace, 2016 


\section{Seccurity}

According to $2016 \mathrm{GPI}$, Europe is still the most peaceful geographical region in the world. Regionally Macedonia and Greece are at the bottom of the list meaning that they are the list peaceful countries in the region. Greece dropped four places globally and regionally it lies ahead only of Republic of Macedonia, which had the biggest drop in the global ranking as a European country, followed by Kosovo. Internal peace and the societal safety and security domain, globally and regionally, declined every year for the last 8 years which to a certain degree is related to the consequences of the global economic crisis. According to the GPI scores since 2008 the world has become less peaceful. (Institute for Economics and Peace, 2016)

"Positive peace" may assume the achievements of negative peace, but in any case moves beyond it to deal with the underlying conflict causes and conditions, through the use of collaborative means to eliminate the structural causes for violence (Sandole, 2007: 41-42). Therefore positive peace means "attitudes, institutions and structures that are creating and maintaining peaceful societies" (Institute for Economic and Peace, 2015). Positive peace is being measured by the Positive Peace Index which is composed of 24 indicators organized in 8 domains, also known as pillars of peace.

Table 9: Positive Peace Index for the Balkan countries

\begin{tabular}{|c|c|c|c|c|c|c|c|c|c|c|}
\hline $\begin{array}{l}\text { 竞 } \\
\text { 总 }\end{array}$ & 竞 & 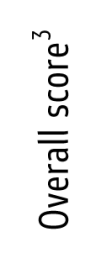 & 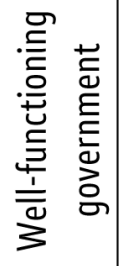 & 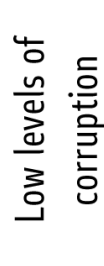 & 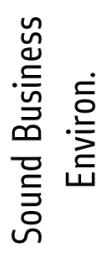 & 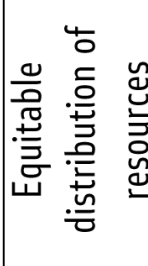 & 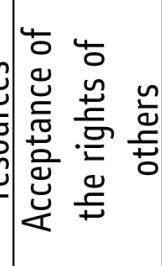 & 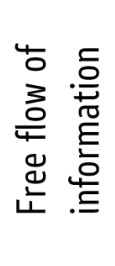 & 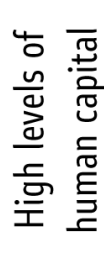 & 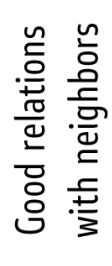 \\
\hline SVN & 22 & 1,921 & 2,474 & 2,265 & 2,463 & & 1,554 & 2,186 & 1,320 & 1,158 \\
\hline GRC & 34 & 2,214 & 2,687 & 2,932 & 2,626 & 1,207 & 2,279 & 2,735 & 1,453 & 1,402 \\
\hline HRV & 36 & 2,268 & 2,667 & 2,922 & 2,824 & 1,634 & 2,261 & 2,550 & 1,544 & 1,402 \\
\hline$B G R$ & 43 & 2,495 & 3,008 & 3,213 & 2,754 & 1,903 & 2,332 & 2,422 & 2,620 & 1,268 \\
\hline MNE & 45 & 2,558 & 2,863 & 3,343 & 2,773 & 1,546 & 2,519 & 2,362 & 2,774 & 1,763 \\
\hline KSV & 46 & 2,564 & 2,180 & 3,791 & 3,116 & 1,463 & 2,658 & 2,639 & 1,517 & 2,665 \\
\hline ROU & 49 & 2,678 & 2,927 & 3,176 & 2,760 & 2,246 & 2,861 & 2,527 & 2,634 & 1,983 \\
\hline MKD & 54 & 2,734 & 2,829 & 3,320 & 2,770 & 1,547 & 2,614 & 2,945 & 2,888 & 2,587 \\
\hline SRB & 59 & 2,783 & 3,078 & 3,583 & 3,280 & 2,115 & 2,835 & 2,439 & 2,251 & 2,226 \\
\hline ALB & 62 & 2,837 & 3,216 & 3,580 & 3,075 & 2,070 & 2,352 & 2,729 & 3,371 & 1,855 \\
\hline $\mathrm{BIH}$ & 68 & 2,955 & 2,799 & 3,687 & 3,452 & 1,916 & 2,971 & 2,787 & 2,956 & 2,627 \\
\hline
\end{tabular}

Source: Institute for Economics and Peace, 2016 


\section{Security}

It is clear that weakest peace pillar in the Balkans is the "low level of corruption" followed by "sound business environment", "well-functioning government" and "high levels in human capital". Greece and Slovenia are among European countries that saw the greatest deterioration in positive peace, but even so Slovenia is with highest level of positive peace in the Balkans followed by Greece, Croatia and Bulgaria. Lowest levels of positive peace are registered in Western Balkan countries, specifically in Bosnia and Hercegovina, Albania, Serbia and Macedonia.

\section{CONCLUSION}

The transition process that started in 1990s along with the global economic crisis that reached the Balkans in 2009, brought sudden insecurities and deprivations, thus increasing the human insecurity throughout the whole region. Unfortunately, WB countries still haven't completed their transition to democracy and liberal market economy, so like in many similar cases their democracy is often referred to as illiberal, captured, partial or alike, while poverty and inequality are still major structural challenge to security. They directly affect people's survival, well-being and quality of life, which are values that are to be protected within the expanded concept of human security. By applying grievance theories of conflict, the research showed how increased poverty and inequality within and between countries, generate conditions within which grievances can lead to growing tensions that might affect stability and security of the Balkans. The results have shown that there are significant and continuous socioeconomic, political and cultural horizontal inequalities in the region, which are undermining democracy and at the same time are increasing the risk of regional destabilization.

The results showed that at individual level poverty and inequality may generate dissatisfaction, grievances and desperation that might cause frustration which may trigger mobilization of discontent that is crucial for aggression and violence. At national level group mobilization can initiate social unrests, ethnical tensions, organized violence, political conflicts and even civil war, thus affecting human as well as national security, mainly when the states are very weak. At regional level, if such developments become violent, they can seriously disturb peace, stability and security of the entire region and lead to intra-national as well as to inter-national tensions and conflicts, particularly if there is overlapping of national and regional discontent of certain ethnic group.

Poverty and inequality as subtle threats to human security are serious source of vulnerability, injustice and insecurity affecting people's fundamental freedoms. Failure of a large part of population to satisfy its vital and biological needs as well as people's perception that their present situation is much worse than expected or compared to others within the society or the region, is creating grievances and makes those people vulnerable to internal and external influences. Therefore, poverty and inequality as source of vulnerability seriously violate people's fundamental "freedom from want". As source of injustice they represent violation of basic human rights as they are provided by the international treaties; and since one of democracy's basic roles is to protect and advance human rights and freedoms, this situation undermines the trust into democracy and violates people's "freedom to live in dignity". Finally, violation of these two freedoms is affecting in- 
dividual safety and security of the people, because it may be a reason for violent conflicts that are directly affecting people's "freedom from fear".

In order to overcome these challenges at national and regional level it will be necessary to gradually reduce and eventually eradicate poverty and horizontal inequalities. At national level WB countries have to complete comprehensive structural reforms, harmonize national with most significant European standards and principles as integral part of the integration process and adopt public policies directed towards poverty and inequality reduction. On the other hand, at regional level this task is becoming much more difficult because in order to reach regional agreement aimed at poverty eradication and reduction of inequalities between the countries, it is necessary to establish substantial and not only formal regional cooperation, which will enable regional and subsequently European integration.

Research findings point out that there is a development - democracy - security link. Economic growth without democracy leads to greater degrees of inequality. That is why democratic governance and economic development are necessary for stabilization and not the other way around. For greater resilience against the current threats to Balkans' security and stability, it is necessary to strengthen security by enhancing countries' economic resilience through sustainable development, inclusive growth, social welfare and even distribution of income and resources; and to consolidate the political resilience through protection and advancement of human rights, rule of law and improved democratic governance.

Increased human insecurity due to poverty and inequality may weaken the national security because their relationship is complementary. Violations of human security manifested as poverty and inequality can easily result in conflicts, displacements and human suffering. Human insecurity weakens human development and worsen human rights thus contributing to the decline of democracy and rise of populism in the region. Therefore, democratization through reduction of poverty and inequality and advancement of human rights and freedoms may contribute to greater human security and stability of the Balkans'.

\section{LITERATURE}

Bartlet, W., 2010. The Social Impact of the Global Economic Crisis in the Western Balkans: with a focus on the Republic of Macedonia, London: European Institute, London School of Economics and Political Science.

Bertelsmann Stiftung , 2017. Publications. [0nline] Available at: https://www.bertelsmann-stiftung.de/en/publications/informational-material/ [Accessed 22 February 2017].

Central Intelligence Agency, 2017. The World Factbook. [Online] Available at: https://www.cia.gov/library/publications/the-world-factbook/ [Accessed 13 March 2017]. 


\section{Security}

Committee on Economic, Social and Cultural Rights, 2001. Statement adopted by by the Committee on econimc, social and cultural rights. [Online]

Available at:

http://www2.ohchr.org/english/bodies/cescr/docs/statements/E.C.12.2001.10Poverty2001.pdf [Accessed 24 February 2017].

Crockett, C., 2011. Challenging the Injustice of Poverty: a Conversation with Rehman Sobhan. [Online]

Available at: http://blog.politics.ox.ac.uk/challenging-the-injustice-of-poverty-a-conversation-with-rehman-sobhan/ [Accessed 7 February 207].

Freedom House, 2016. Nations in Transit. [Online] Available at: https://freedomhouse.org/report/nations-transit/nations-transit-2016 [Accessed 22 February 2017].

Fund for Peace, 2016. Fragile State INdex. [Online] Available at: http://fsi.fundforpeace.org/rankings-2016 [Accessed 12 February 2017].

Gurr, T. R., 2011. Why Men Rebel. 40th ed. s.l.:Paradigm Publishers.

Halperin, M. H., Siegle, J. T. \& Weinstein, M. M., 2005. The Democracy Advantage: How Democracies Promote Prosperity and Peace. 1st ed. New York: Routledge.

Hong Hai, N., 2007. Human Rights-Human Security_Human Development:Assessing the inter-relationships of human development, human security and human rights in poverty reduction in Vietnam. University of Thailand Conference: s.n.

Institute for Economics and Peace, 2016. Reports. [Online] Available at: http://economicsandpeace.org/reports/ [Accessed 16 March 2017].

International Federation of Social Workers, 2017. Poverty, a key issue for social justice. [Online] Available at: http://ifsw.org/publications/human-rights/poverty-a-key-issuefor-social-justice [Accessed 10 February 2017].Jeleva, R., 2012. The Impact of the Crisis on the EU Perspective of the Western Balkans, Brussels: Centre for European Studies. Large, J. \& Sisk, T. D., 2006. Democracy, Conflict and Human Security: Pursuing Peace in the 21st Century. Stockholm: International Institute for Democracy and Eloctoral assistance (IDEA).

Organisation for Economic Cooperation and Development, 2017. National Accounts. [Online] Available at: http://www.oecd.org/std/na/ [Accessed 15 March 2017].

Orovcanec, A., 2016. The influence of the global economic crisis and socioeconomic and development discrepancies on the peace, stability and security in the Balkans' region, Skopje: University of Ss. Cyril and Methodius . 


\section{Securitity}

Sandole, D. J., 2007. Peace and Security in the Postmodern World: The OSCE and Conflict Resolution. 1st yp. New York: Routledge.

Spoor, M., 2005. Inequality, Rural Poverty and Conflict in Transition Economies. In: M. Spoor, ed. Globalization, Poverty and Conflict: A Critical Development Reader. New York: Kluwer Academic Publishers, pp. 47-65.

Stewart, F., 2002. Horizontal Inequalities: A Neglected Dimension of Development, 0xford: Queen Elizabeth House, University of Oxford.

UN General assembly, 2005. Resolution adopted by the General Assembly. [Online] Available at:

https://documents-dds-ny.un.org/doc/UNDOC/GEN/N05/487/60/PDF/N0548760.pdf?OpenElement [Accessed 24 February 2016].

UNDP, 2016. International Human Development Indicators. [Online]

Available at: http://hdr.undp.org/en/countries [Accessed 15 March 2017].

World Bank, 2016. World Bank Indicators. [Online] Available at:

http://data.worldbank.org/indicator [Accessed 14 March 2017].

World Bank, 2017. PovcalNet. [Online]

Available at: http://iresearch.worldbank.org/PovcalNet/pov0nDemand.aspx [Accessed 14 March 2017]. 